\title{
Penetapan Kadar Tetrasiklin dalam Air Limbah dengan High Performance Liquid Chromatography-Photodiode Array Detector (HPLC-PDA)
}

\section{(Determination of Tetracycline in Wastewater Samples by High Performance Liquid Chromatography-Photodiode Array Detector (HPLC-PDA))}

\section{Sanjayadi $^{1^{*}, \text { Laurentia Brenda Violita }}{ }^{1}$}

${ }^{1 *}$ Fakultas Kedokteran dan Ilmu Kesehatan, Universitas Katolik Indonesia Atma Jaya, Jakarta, Indonesia. E-mail:sanjayadi@atmajaya.ac.id

\author{
Article Info: \\ Received: 23 April 2020 \\ in revised form: 11 Mei 2020 \\ Accepted: 27 Juli 2020 \\ Available Online: 30 September \\ 2020 \\ Keywords: \\ Tetracycline \\ HPLC-PDA \\ Environment \\ Waters \\ Tropical \\ Corresponding Author: \\ Sanjayadi \\ Faculty of Medicine and Health \\ Sciences \\ Atma Jaya Catholic University of \\ Indonesia \\ Jakarta \\ 14440 \\ Indonesia \\ email: sanjayadi@atmajaya.ac.id
}

\begin{abstract}
Tetracycline is an antibiotic that widely used for human treatment and veterinary. Tetracycline is also known as one of the persistent antibiotics in environment. This study aims to develop and validate analysis method for tetracycline in wastewater samples and use this method to determine tetracycline concentration in wastewater samples. The analysis is carried out by extracting samples using SPE C18 and tetracycline was determined by using high-performance liquid chromatography equipped with photodiode array (HPLC-PDA) detector that has been optimized and validated. The result of this study revealed that the developed method was valid enough to determine tetracycline in the range of $0.21-3.16 \mu \mathrm{g} / \mathrm{mL}$ showed by the correlation coefficient of 0.999 , limit detection and quantification of $0.102 \mu \mathrm{g} / \mathrm{mL}$ and $0.340 \mu \mathrm{g} / \mathrm{mL}$ respectively, precision (RSD) of $5.2-5.6 \%$ (intra-day) and $4.8-5.7 \%$ (inter-day) respectively and accuracy (\% recovery) of $94.6 \%$. This study shows that tetracycline was not detected in the analyzed wastewater samples.
\end{abstract}




\begin{abstract}
ABSTRAK
Tetrasiklin merupakan antibiotik yang banyak digunakan baik untuk pengobatan pada manusia maupun veteriner serta merupakan salah satu antibiotik yang persisten di lingkungan. Penelitian ini bertujuan untuk mengembangkan dan memvalidasi metode analisis tetrasiklin dalam sampel air limbah dan menggunakannya untuk menetapkan kadar tetrasiklin dalam sampel air limbah. Analisis dilakukan dengan mengekstraksi sampel menggunakan SPE C18 dan dilanjutkan tahap determinasi menggunakan metode High Performance Liquid Chromatography yang dilengkapi dengan detektor foto-dioda (HPLC-PDA) yang sebelumnya telah dioptimasi dan divalidasi. Hasil penelitian ini menunjukkan bahwa metode analisis yang dikembangkan cukup valid pada kisaran konsentrasi tetrasiklin $0,21-3,16 \mu \mathrm{g} / \mathrm{mL}$ yang ditunjukkkan dengan koefisien korelasi sebesar 0,999, batas deteksi dan kuantifikasi berturut-turut $0,102 \mu \mathrm{g} / \mathrm{mL}$ dan $0,340 \mu \mathrm{g} / \mathrm{mL}$ dengan kepresisian (RSD) 5,2 - 5,6\% dan 4,8 - 5,7\% (berturut-turut intra-day dan inter-day) serta keakuratan (persen perolehan kembali) 94,6\%. Hasil penelitian ini juga menunjukkan bahwa tetrasiklin tidak terdeteksi dalam sampel air limbah yang dianalisis.
\end{abstract}

Kata kunci: Tetrasiklin; HPLC-PDA; lingkungan; air; tropis

\title{
1. PENDAHULUAN
}

Antibiotik adalah obat antimikroba yang membunuh atau menghambat pertumbuhan bakteri. Antibiotik telah digunakan dalam jumlah besar selama beberapa dekade dan resistensi patogen terhadap antibiotik telah lama menjadi titik fokus penelitian klinis dan, dalam beberapa tahun terakhir, dalam penelitian lingkungan. Senyawa induk dari antibiotik, atau metabolitnya, dapat cukup stabil sehingga dapat lolos selama proses pengolahan air dan masuk ke lingkungan (Kümmerer, 2009). Meskipun telah mengalami pengenceran dengan faktor pengenceran lebih dari satu juta dibandingkan dengan konsentrasi dalam tubuh manusia (Jjemba, 2006), antibiotik yang tersebar di lingkungan mempunyai konsekuensi penting bagi kesehatan manusia dan ekosistem.

Ada tiga jalur utama untuk antibiotik ke perairan air tawar: (1) limbah dari IPAL, (2) pabrik kimia serta (3) peternakan dan akuakultur (Kümmerer, 2009; Singer et al., 2016). Diperkirakan konsumsi antibiotik di seluruh dunia berkisar antara 100.000 dan 200.000 ton per tahun, dengan sekitar 50\% digunakan untuk kedokteran hewan dan sebagai pemacu pertumbuhan. Konsumsi antibiotik global oleh manusia meningkat sebesar 36\% antara tahun 2000 dan 2010 yang menggambarkan bahwa polusi antibiotik adalah masalah yang terus bertambah (Van Boeckel et al., 2014).

Residu antibiotik yang mengkontaminasi air tanah mempunyai resiko menyebabkan toksisitas langsung pada manusia yang meminum air tersebut (Martinez, 2009). Residu antibiotik yang berada dalam tanah ditengarai dapat mengganggu kesetimbangan ekosistem mikrobia dalam tanah, terutama mikrobia fiksasi nitrogen yang menyediakan unsur hara dalam tanah, sehingga mempengaruhi kesuburan tanah. Dampak lain yang saat ini menjadi perhatian adalah kemungkinan terjadinya resistensi mikroba terhadap antibiotik akibat adanya residu antibiotik di lingkungan, khususnya lingkungan perairan. Beberapa gen resisten mikroba patogen pada manusia dan hewan berasal dari bakteri tidak berbahaya di lingkungan (Wellington et al, 2013; Finley et al., 2013; Gaze et al., 2013).

Keberadaan residu di lingkungan perairan telah banyak dilaporkan di beberapa negara, namun demikian data adanya antibitiok di lingkungan perairan daerah tropis masih sangat terbatas. Oleh karena itu, penelitian ini bertujuan untuk mengembangkan metode analisis antibiotik, khususnya tetrasiklin, dalam matriks air dan mengaplikasikannya untuk menetapkan kadar antibiotik tersebut dalam sampel air limbah. Tetrasiklin dipilih karena merupakan antibiotik yang sering digunakan di Indonesia yang merupakan daerah tropis. PDA dapat mendeteksi pada rentang panjang gelombang tertentu secara bersamaan sehingga mampu menyajikan kromatogram dalam bentuk 3 dimensi. Oleh karena itu detektor ini juga dapat memberikan informasi kemurnian puncak. Sementara itu, jika menggunakan detektor UV-Vis, maka ketidakmurnian puncak tidak dapat teramati. 


\section{METODE PENELITIAN}

\subsection{Alat dan Bahan}

HPLC yang digunakan LC-20AD Prominance LC (Shimadzu) yang dilengkapi detektor foto-dioda (PDA) SPD-M20A Prominance LC (Shimadzu) dengan kolom Triart-C8 (150,0 x 6,0 mm, $5 \mathrm{uM})$ (YMC). Tetrasiklin kualitas analisis (Sigma Aldrich), monosodium fosfat dan asam fosfat kualitas analisis (Merck), asetonitril kualitas HPLC (Merck), air bebas ion merupakan air yang dimurnikan dengan menggunakan Elga water deionizer, SPE C18 (Waters). Sampel air limbah merupakan air selokan yang diperoleh dari selokan yang berada di sekitar Rumah Sakit Atma Jaya, Jakarta.

\subsection{Metode}

\section{Pembuatan larutan stok standard tetrasiklin}

Stok larutan tetrasiklin dibuat dengan konsentrasi $0,75 \mathrm{mg} / \mathrm{mL}$ dalam air bebas ion, disimpan dalam lemari pendingin pada suhu $4^{\circ} \mathrm{C}$, terhindar dari cahaya dan digunakan paling lama 48 jam setelah dibuat. Larutan stok ini digunakan untuk melakukan validasi metode analisis yang digunakan yang meliputi rentang dan linearitas, batas deteksi dan kuantifikasi, presisi (repeatibilitas, reprodusibilitas) serta akurasi.

\section{Optimasi HPLC-PDA}

Dilakukan pada termperatur ruangan. Fase gerak (A) buffer fosfat dengan konsentrasi $1 \times 10^{-2} \mathrm{M}$ dalam air dan (B) asetonitril. Optimasi dilakukan dengan mengubah $\mathrm{pH}$ buffer fosfat yaitu 2, 4 dan 6 serta mengatur perbandingan buffer fosfat dan asetonitril. Kecepatan fase gerak $1 \mathrm{~mL} / \mathrm{menit}$ dan volume injeksi $20 \mathrm{uL}$. Deteksi dengan detektor PDA pada panjang gelombang antara 290-400 nm (panjang gelombang maksimum untuk kuantifikasi $350 \mathrm{~nm}$ ).

\section{Validasi Metode Analisis}

Validasi metode analisis yang digunakan yang meliputi rentang dan linearitas, batas deteksi dan kuantifikasi mengikuti Miller dan Miller (2010), presisi (repeatibilitas, reprodusibilitas) serta akurasi mengikuti Latimer (2016).

\section{Pengambilan dan Preparasi Sampel}

Metode yang telah tervalidasi digunakan untuk mendeterminasi tetrasiklin dalam sampel air limbah berupa air selokan yang berada dekat Rumah Sakit Atma Jaya Jakarta. Air dikumpulkan dengan menggunakan botol kaca coklat. Satu liter sampel disaring dan diekstraksi menggunakan SPE C18 dan menyaring fraksi metanol $(5,0 \mathrm{~mL})$ dengan membran filter $0,45 \mu \mathrm{m}$. Sebagai kontrol positif, dilakukan juga penambahan larutan stok standard tetrasiklin pada sampel air yang digunakan.

\section{HASIL DAN PEMBAHASAN}

\subsection{VALIDITAS METODE ANALISIS}

Hasil optimasi determinasi tetrasiklin dalam sampel yang telah dilakukan dalam penelitian ini ditunjukkan oleh Tabel 1. Terlihat bahwa kondisi optimal tercapai pada penggunaan fase gerak berupa campuran buffer fosfat dengan $\mathrm{pH} 2\left(1 \times 10^{-2} \mathrm{M}\right)$ dalam air dan asetonitril dengan perbandingan 75:25 (v/v) yang ditunjukkan oleh nilai efisiensi yang cukup tinggi yaitu sekira 4700 dan bentuk puncak yang simetris dengan nilai tailing factor 1,06. Kondisi HPLC pada $\mathrm{pH}$ yang sama dengan perbandingan air dan asetonitril 80:20 (v/v) juga memiliki nilai efisiensi yang cukup tinggi, namun karena nilai faktor retensi yang lebih besar maka menyebabkan kurang simetrisnya puncak yang terbentuk yang ditunjukkan oleh nilai tailing factor sebesar 1,67. 
Tabel 1. Hasil optimasi fase gerak untuk determinasi tetrasiklin dengan HPLC-PDA

\begin{tabular}{cccccc}
\hline pH buffer & $\begin{array}{c}\text { Konsentrasi } \\
\text { asetonitril } \\
\text { (\% v/v) }\end{array}$ & $\begin{array}{c}\text { Waktu } \\
\text { retensi } \\
\text { (menit) }\end{array}$ & $\begin{array}{c}\text { Faktor } \\
\text { retensi }\end{array}$ & Efisiensi & $\begin{array}{c}\text { Tailing } \\
\text { factor }\end{array}$ \\
\hline tanpa & 20 & 4.2 & 2.05 & 6782 & 2.19 \\
buffer & 25 & 2.8 & 1.05 & 3836 & 0 \\
& 30 & 2.2 & 0.59 & $\mathrm{NA}^{*}$ & $\mathrm{NA}^{*}$ \\
$\mathbf{2}$ & 20 & 4.7 & 2.48 & 4780 & 1.67 \\
& 25 & 3.1 & 1.32 & 4706 & 1.06 \\
& 30 & 2.4 & 0.74 & $\mathrm{NA}^{*}$ & $\mathrm{NA}^{*}$ \\
$\mathbf{4}$ & 20 & 4.2 & 2.08 & 4301 & 1.32 \\
& 25 & 2.6 & 0.94 & 4503 & 1.09 \\
& 30 & 2.1 & 0.54 & $\mathrm{NA}^{*}$ & $\mathrm{NA}^{*}$ \\
$\mathbf{6}$ & 20 & 3.5 & 1.58 & 5420 & 1.11 \\
& 25 & 2.3 & 0.72 & $\mathrm{NA}^{*}$ & $\mathrm{NA}^{*}$ \\
& 30 & 2.1 & 0.57 & $\mathrm{NA}^{*}$ & $\mathrm{NA}^{*}$ \\
\hline
\end{tabular}

Keterangan. NA*: tidak dapat ditentukan

Pada sistem HPLC-PDA yang digunakan, waktu retensi tetrasiklin adalah $\pm 3,1$ menit seperti yang ditunjukkan oleh Gambar 1.

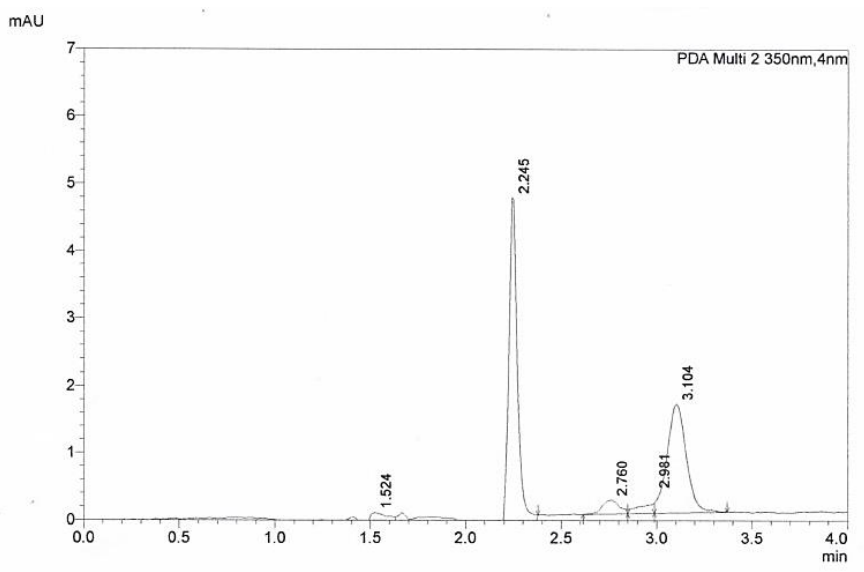

Gambar 1. Kromatogram standar tetrasiklin.

Linearitas metode determinasi tetrasiklin yang digunakan dalam penelitian ini menunjukkan bahwa terdapat hubungan yang linear antara konsentrasi tetrasiklin dan respon alat yaitu luas puncak tetrasiklin pada rentang konsentrasi $0,21-3,16 \mu \mathrm{g} / \mathrm{mL}$ yang mengikuti persamaan garis lurus $\mathrm{Y}=$ $(25162,1 \pm 885,4) \mathrm{X}+(1483,4 \pm 1385,1)$ dengan nilai koefisien korelasi $(r) 0,999$ pada batas kepercayaan $95 \%$.

Batas determinasi dan kuantifikasi metode pengukuran tetrasiklin dengan menggunakan HPLC-PDA yang digunakan berturut-turut adalah $0,102 \mu \mathrm{g} / \mathrm{mL}$ dan $0,340 \mu \mathrm{g} / \mathrm{mL}$ yang ditentukan dengan menggunakan metode Miller and Miller (2010) menunjukan bahwa metode yang digunakan cukup sensitif untuk mengukur tetrasiklin dalam sampel.

Presisi (RSD) metode pengukuran intra-day dan inter-day berturut turut adalah 5,2 - 5,6\% dan 4,8 $5,7 \%$ yang menunjukkan bahwa metode yang digunakan masih cukup presisi pada rentang kadar yang 
diukur. Pada penelitian ini, diperoleh nilai persen perolehan kembali 94,6\% yang menunjukkan bahwa metode yang digunakan cukup akurat pada rentang kadar yang diukur (Latimer, 2016).

\subsection{ANALISIS SAMPEL AIR LIMBAH}

Hasil pengukuran tetrasiklin yang dilakukan menunjukkan bahwa tetrasiklin tidak terdeteksi dalam sampel air selokan yang dianalisis (Gambar 2).

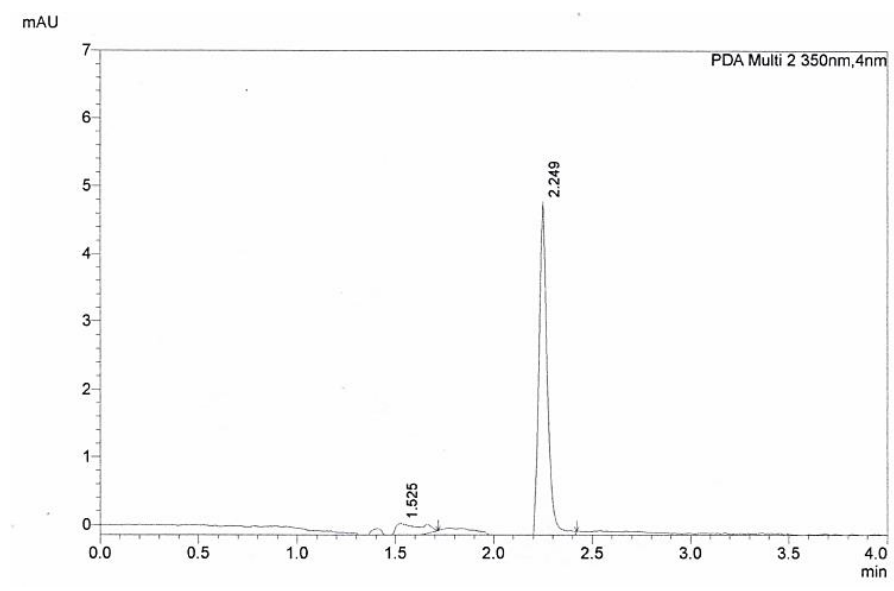

Gambar 2. Kromatogram sampel air selokan.

Untuk memastikan bahwa metode ini dapat digunakan untuk mendeteksi tetrasiklin dalam sampel air yang digunakan, maka dalam penelitian ini juga dilakukan analsisi sampel air selokan yang ditambah dengan tetrasiklin dan hasilnya ditunjukkan oleh Gambar 3. Hal ini dapat membuktikan bahwa metode ini dapat digunakan untuk menganalisis tetrasiklin dalam sampel dalam air selokan tersebut.

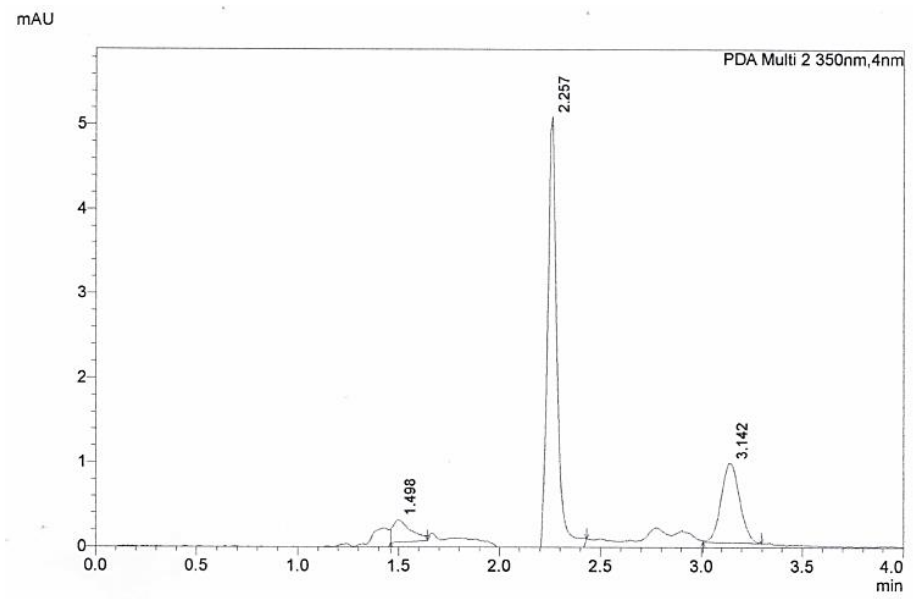

Gambar 1. Kromatogram sampel air dengan penambahan tetrasiklin $0,52 \mu \mathrm{g} / \mathrm{mL}$.

\section{KESIMPULAN}

Dari penelitian ini dapat disimpulkan bahwa metode analisis tetrasiklin yang dikembangkan dalam penelitian ini layak digunakan untuk menetapkan konsentrasi tetrasiklin dalam matrik air yang digunakan. Penelitian ini juga menunjukkan bahwa tetrasiklin tidak terdeteksi dalam sampel air selokan yang diamati dengan metode analisis yang digunakan. Selanjutnya perlu untuk dikembangkan metode analisis yang lebih sensitif untuk mendeteksi tetrasiklin di lingkungan perairan. 


\section{UCAPAN TERIMAKASIH}

Penelitian ini dilakukan dengan menggunakan anggaran penelitian Unika Atma Jaya melalui Lembaga Penelitian dan Pengabdian kepada Masyarakat Unika Atma Jaya (LPPM Unika Atma Jaya). Penulis mengucakan terima kasih kepada LPPM Unika Atma Jaya dan Pusat Penelitian Kesehatan Fakultas Kedokteran dan Ilmu Kesehatan Unika Atma Jaya.

\section{DAFTAR PUSTAKA}

Finley, R. L., Collignon, P., Larsson, D. G. J., McEwen, S. A., Li, X. Z., Gaze, W. H., et al. (2013). The scourge of antibiotic resistance: the important role of the environment. Clinical Infectious Diseases, 57:704-10.

Gaze, W. H., Krone, S. M., Larsson, D. G. J., Li, X. Z., Robinson, J. A., Simonet, P., et al. (2013). Influence of humans on evolution and mobilization of environmental antibiotic resistome. Emerging Infectious Diseases, 19:7.

Jjemba, P. K., (2006). Excretion and ecotoxicity of pharmaceutical and personal care products in the environment. Ecotoxicology and Enviromental Safety, 63, 113-130.

Kümmerer, K. (2009). Antibiotics in the aquatic environment-a review-part I, Chemosphere, 75, 417434.

Latimer, G. W. Jr. (2016). Official Methods of Analysis of AOAC International (20 ${ }^{\text {th }}$ ed.). Maryland, USA: AOAC International.

Martinez, J. L. (2009). The role of natural environments in the evolution of resistance traits in pathogenic bacteria. Proceedings of the Royal Biol Society B: Biologycal Sciences, 276:252130.

Miller, J. N., Miller, J. C. (2010). Statistics and Chemometrics for Analytical Chemistry (6 ${ }^{\text {th }}$ ed.). Gosport, UK: Pearson Education Limited.

Singer, A. C., Shaw, H., Rhodes, V., Hart, A.. (2016). Review of antimicrobial resistance in the environment and its relevance to environmental regulators. Frontiers in Microbiology, 7, 1-22.

Van Boeckel, T. P., Gandra, S., Ashok, A., Caudron, Q., Grenfell, B. T., Levin, S. A., Laxminarayan, R. (2014). Global antibiotic consumption 2000 to 2010: an analysis of national pharmaceutical sales data. Lancet Infectious Diseases, 14, 742-750.

Wellington, E. M. H., Boxall, A. B. A., Cross, P., Feil, E. J., Gaze, W. H., Hawkey, P. M., et al. (2013). The role of the natural environment in the emergence of antibiotic resistance in Gramnegative bacteria. Lancet Infectious Diseases, 13:155-65. 